\title{
Somatic embryogenesis from in vitro anther culture of apomictic buffel grass genotypes and analysis of regenerated plants using flow cytometry
}

\author{
Edgardo Carloni - Andrea Ribotta $\cdot$ Eliana López Colomba • \\ Sabrina Griffa $\cdot$ Mariana Quiroga $\cdot$ Exequiel Tommasino • \\ Karina Grunberg
}

Received: 25 October 2013/Accepted: 1 February 2014

(C) Springer Science+Business Media Dordrecht 2014

\begin{abstract}
Buffel grass is a fodder grass that reproduces mainly via apomixis. Using in vitro tissue culture in apomictic species provides alternatives that can be applied in a breeding program. The aims of this work were to establish a protocol for in vitro generation of apomictic buffel grass genotypes using anthers as explants and to evaluate the genetic stability of regenerated plants via flow cytometry (FCM). Three genotypes were able to induce embryogenic calli in Murashige and Skoog (MS) medium supplemented with $6 \mathrm{mg} / \mathrm{l}$ of 2,4-dichlorophenoxyacetic acid. Seedling regeneration occurred in a MS medium supplemented with $0.5 \mathrm{mg} / \mathrm{l}$ napthaleneacetic acid $+1 \mathrm{mg} / \mathrm{l}$ 6-benzylaminopurin. Seedlings were derived from somatic embryos and the morphogenic process was induced using the somatic tissue of the stamens. Induction and regeneration efficiency depended on the genotype and was affected by date of tiller collection, different pretreatments or the interaction of these variables. FCM analyses in in vitro regenerated plants showed genetic instability in their nuclear DNA content. Plants with lower nuclear DNA content may indicate DNA aneuploids $(8.6 \%)$, whereas plants that had twice the value of nuclear DNA content (4.7\%) suggest in vitro polyploidization. This variation observed in apomictic genotypes provides an opportunity to obtain new variants, which may then be included as sources of genetic variability in buffel grass breeding programs.
\end{abstract}

E. Carloni $(\bowtie) \cdot$ A. Ribotta · E. López Colomba · S. Griffa · M. Quiroga · E. Tommasino · K. Grunberg

Instituto de Fisiología y Recursos Genéticos Vegetales (IFRGV), Centro de Investigaciones Agropecuarias (CIAP), Instituto Nacional de Tecnología Agropecuaria (INTA), Avenida 11 de setiembre 4755, C.P. X5020ICA Córdoba, Argentina

e-mail: edgardocarloni@gmail.com
Keywords Apomixis - Nuclear DNA content - Somatic embryo $\cdot$ Plant breeding $\cdot$ Somaclonal variation

Abbreviations
$\begin{array}{ll}\text { FCM } & \text { Flow cytometry } \\ \text { 2,4-D } & \text { 2,4-Dichlorophenoxyacetic acid } \\ \text { NAA } & \text { Napthaleneacetic acid } \\ \text { BAP } & \text { 6-Benzylaminopurin } \\ \text { MS } & \text { Murashige and Skoog (1962) medium } \\ \text { BAC } & \text { Beginning of anther culture } \\ \text { PEC } & \text { Proportion of embryogenic calli } \\ \text { NRS } & \text { Number of regenerated seedlings }\end{array}$

\section{Introduction}

Buffel grass [Pennisetum ciliare (L.) Link syn. Cenchrus ciliaris L.] is a drought-tolerant, summer-growing perennial fodder grass adapted to arid and semiarid regions worldwide (Hanselka et al. 2004). The species reproduces primarily by apomixis via apospory followed by pseudogamy (Fisher et al. 1954; Snyder et al. 1955; Jessup et al. 2003). Apomictic plants produce progeny that are identical to the female parent, providing the opportunity to select an individual plant and propagate it as clones through seeds (Hanna and Bashaw 1987). However, conducting a conventional breeding program involving apomictic species is difficult. The advent of biotechnological techniques has contributed with useful tools for plant breeding. One of those tools is in vitro tissue culture, which might be useful as a source for transformation (Bhat et al. 2001) or because it promotes somaclonal variation (Larkin and Scowcroft 1981).

Several works with buffel grass have shown successful in vitro culture establishment using different types of 
explants, such as inflorescences (Kackar and Shekhawat 1991; Murty et al. 1992), seeds (Ross et al. 1995; Bhat et al. 2001), mature embryos (Colomba et al. 2006) and shoot tips (Yadav et al. 2009; Kumar and Bhat 2012). Somatic embryogenesis is usually the most commonly observed morphogenic process (Ross et al. 1995; Bhat et al. 2001; Colomba et al. 2006; Yadav et al. 2009); however, plant regeneration via multiple-shoot induction has been recently mentioned (Kumar and Bhat 2012). Some cultivars have been found to remain recalcitrant to somatic embryogenesis (Colomba et al. 2006). In addition, the induction of embryogenic calli and seedling regeneration largely depend on the genotype or the explant (Colomba et al. 2006; Yadav et al. 2009). Because genotype effects are unavoidable, using explants other than those mentioned above might be a strategy to improve regeneration efficiency or allow the establishment of those genotypes that do not respond to the in vitro culture.

A possible alternative is to induce somatic embryogenesis and further seedling regeneration by using anther explants. Although in vitro anther culture is usually used to obtain doubled-haploid plants (Salas et al. 2011; ParraVega et al. 2012), it has also been efficiently used to obtain somatic-derived plants in several ornamental crops (Niimi et al. 2001; Chen et al. 2005; Winarto et al. 2011) and grapevines (Faure et al. 1996; Perrin et al. 2004; LópezPérez et al. 2005; Leal et al. 2006). Before culture, anthers are usually subjected to different pretreatments, such as cold or manitol stress, or their combination, to increase the number of produced embryos and regenerated plants $(\mathrm{Ci}-$ stué et al. 1999; Kruczkowska et al. 2002; Labbani et al. 2007). To our knowledge, there are no recorded attempts to regenerate buffel grass using anthers.

In vitro-regenerated plants are known to express variations from mother plants (Larkin and Scowcroft 1981). These changes, which are related to genetic stability of in vitro regenerated plants, might be produced by variations in DNA content (polyploidy or aneuploidy) or nuclear DNA structure (point mutations) (Pfosser et al. 1995; Jain 2001; Roux et al. 2003; Clarindo et al. 2008; Currais et al. 2013). In general, the changes observed can be associated with influencing factors, such as genotype (Tremblay et al. 1999), growth regulators (Lim and Loh 2003; May and Sink 1995; Jin et al. 2008; Clarindo et al. 2008) or stress due to the duration of the in vitro culture (Endemann et al. 2001). Many of these variants are usually detected through phenotypic evaluation (Tremblay et al. 1999; Winarto et al. 2011) but when the changes are not so evident, it becomes necessary to use other tools for their identification.

In the last decades, measuring nuclear DNA content by flow cytometry (FCM) has been suggested as an alternative tool to evaluate genetic stability (Leal et al. 2006; Doležel et al. 2007). This technique allows us to detect small and large variations in the nuclear DNA content (Pfosser et al. 1995; Roux et al. 2003; Leal et al. 2006; Prado et al. 2010) and has the advantage of analyzing numerous samples in a short period (Lysák and Doležel 1998; Doležel et al. 2007). FCM was used in buffel grass to characterize different accessions (Burson et al. 2012; Kharrat-Souissi et al. 2012), showing the suitability of this technique to detect materials with different DNA ploidy levels.

The aims of this work were to provide a protocol for in vitro regeneration in apomictic genotypes of buffel grass using anther as explants and to evaluate the genetic stability of regenerated plants using FCM.

\section{Materials and methods}

\section{Plant material}

Donor apomictic plants used to obtain anthers were derived from three genotypes of register numbers $(\mathrm{RN})$ : 51, 147 and 158, of the active buffel grass collection from the Instituto de Fisiología y Recursos Genéticos Vegetales of the Instituto Nacional de Tecnología Agropecuaria (INTA), Córdoba, Argentina.

\section{Anther culture}

Plant material was collected early in the morning on January 28, February 15 and March 2, 2010. Anthers containing microspores in the uninucleate stage (Fig. 1a) were obtained from tillers with spikes at the boot stage, when the distance between the ligule of the flag leaf and that of the penultimate leaf was between 1 and $3 \mathrm{~cm}$ (Fig. 1b). Leaves were discarded and spikes were disinfected by immersion in $70 \%$ ethanol $(\mathrm{v} / \mathrm{v})$ for $1 \mathrm{~min}$, then in $10 \%$ commercial sodium hypochlorite $(55 \mathrm{~g} / \mathrm{l})$ with three drops of Tween 20 , and 5 drops of $1 \mathrm{~N}$ hydrochloric acid for $15 \mathrm{~min}(100 \mathrm{ml}$ of solution v/v). Finally, the spikes were rinsed five times with distilled water under laminar flow chamber. The anthers were detached from the filament base (Fig. 1c) and cultivated in an induction medium, which consisted of basal MS medium (Murashige and Skoog 1962), $3 \%$ sucrose $(\mathrm{p} / \mathrm{v})$ and $6 \mathrm{mg} / \mathrm{l}$ 2,4-dichlorophenoxyacetic acid (2,4-D). The medium was adjusted to a $\mathrm{pH}$ of 5.8 and solidified with agar $(7 \mathrm{~g} / \mathrm{l})$ before autoclaving for $20 \mathrm{~min}$ at $116{ }^{\circ} \mathrm{C}$. For each collection date, 30 anthers (10 flowers) were cultured in each Petri dish $(35 \mathrm{~mm})$, using six replications. The three anthers from each central flower (fertile anthecium) were grouped and considered an explant (Fig. 1c).

The control group consisted of explants cultured on the same collection date. To promote embryogenic response, pretreatments were performed: tillers collected on the same 

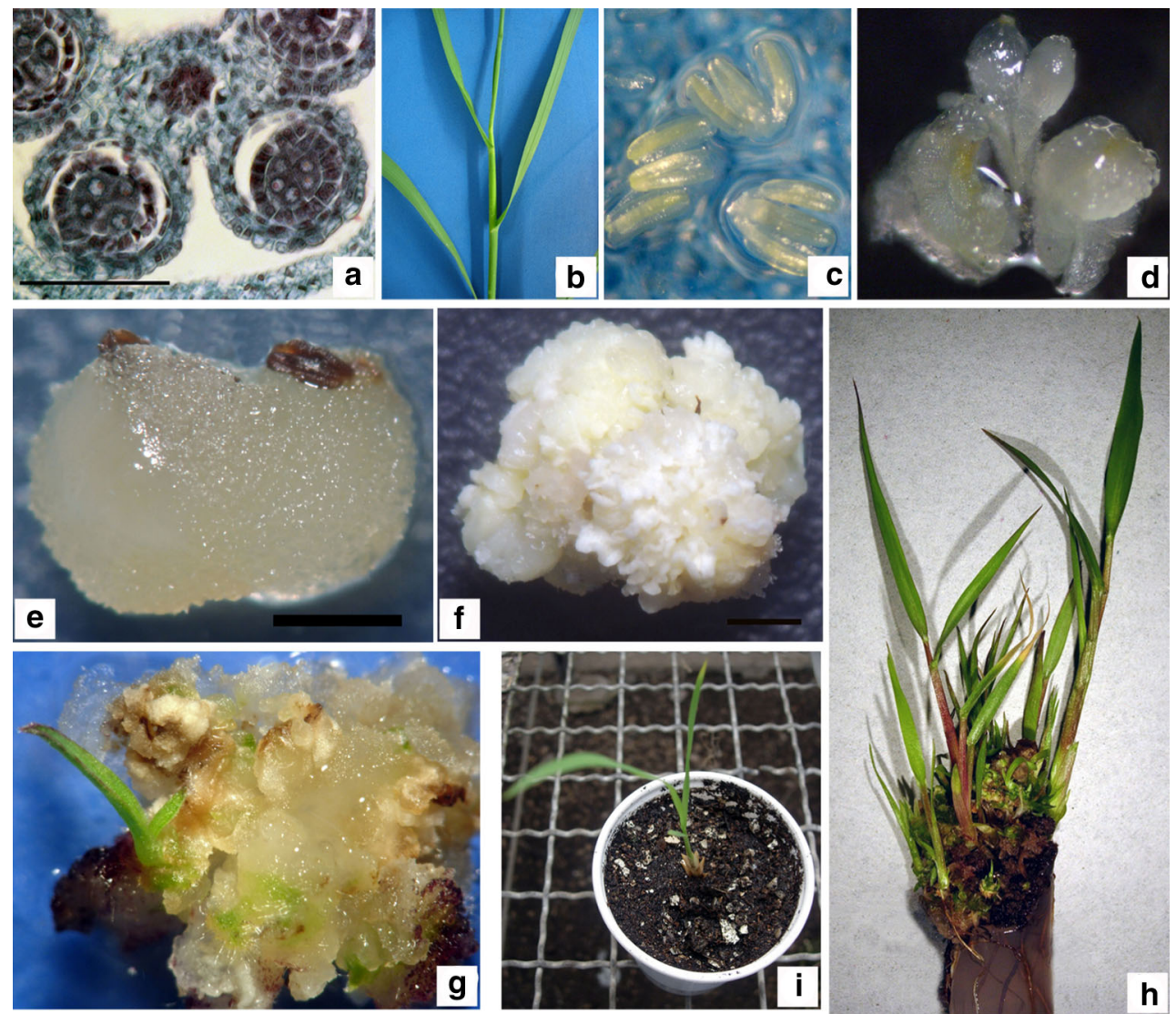

Fig. 1 Callus development and plant regeneration from anther in vitro culture in buffel grass. a Transverse section of anther with uninucleate microspores (scale bar $100 \mu \mathrm{m}$ ). b Tiller with spike at the boot stage and $\mathbf{c}$ anthers at the moment of culture. $\mathbf{d}$ Calli during the induction period 7 days after the beginning of anther culture (BAC). e Non-embryogenic callus and $\mathbf{f}$ embryogenic callus at 60 days after BAC (scale bar $1 \mathrm{~mm}$ ). g First shoots from embryogenic callus and $\mathbf{h}$ entire seedlings obtained in the regeneration medium. i Plant in greenhouse after the hardening period

sucrose and $0.5 \mathrm{mg} / 1 \mathrm{NAA}$ (rooting medium) to promote rooting. Rooting and regeneration media were adjusted to $5.8 \mathrm{pH}$, solidified with agar $(7 \mathrm{~g} / \mathrm{l})$ and autoclaved for $20 \mathrm{~min}$ at $116{ }^{\circ} \mathrm{C}$. The tubes were placed under controlled conditions (temperature: $25 \pm 2{ }^{\circ} \mathrm{C}$; photoperiod: $16 \mathrm{~h}$ light and $8 \mathrm{~h}$ darkness). Rooted seedlings were transplanted into 50-ml plastic containers containing soil and vermiculite (1:1) and hardened in a greenhouse (acclimation period) in a humidity-saturated environment. Then they were transferred to plastic pots ( $1 \mathrm{~kg}$ capacity) and taken to the field where they flowered.

\section{Histological observations}

Development of somatic embryos into calli was confirmed by histological sections. Calli of 15 to 20 days of BAC were fixed in a mixture of ethanol: water: formalin: glacial acetic acid (FAA, 5: 3.5: 1: 0.5) for $48 \mathrm{~h}$. They were then placed in $70 \%$ ethanol (v/v). Samples were dehydrated in a series of ethanol dilutions $(70 \%, 96 \%, 100 \% \mathrm{v} / \mathrm{v})$ and calli were embedded in paraffin using the conventional ferred individually to glass tubes with MS medium, $1.5 \%$ 
technique of D'Ambrogio de Argüeso (1986). Sections $(10 \mu \mathrm{m})$ obtained with a rotary microtome (Accu-Cut ${ }^{\circledR}$ SRM 200 CW) were stained with Safranin and Fast Green and observed under a light microscope.

\section{Flow cytometry}

Nuclear DNA content of the three anther-donor genotypes and regenerated plants was determined using FCM. The samples were processed following the protocol in Doležel et al. (2007), with modifications. Leaf segments $\left(4-6 \mathrm{~cm}^{2}\right)$ of buffel grass and of the reference standard [Zea mays CE777 (2C $=5.43$ pg DNA)] (Lysák and Doležel 1998) were chopped all together in $1 \mathrm{ml}$ Otto I buffer $(0.1 \mathrm{M}$ citric acid monohydrate, $0.5 \%$ Tween 20) (Otto 1990). After filtering the samples through a $30 \mu \mathrm{m}$ mesh sieve, they were centrifuged at 1,500 $\mathrm{rpm}$ for $5 \mathrm{~min}$ and the supernatant was removed. Pellets were resuspended in $100 \mu$ l Otto 1 buffer with mild agitation and incubated in cold chamber $\left(4^{\circ} \mathrm{C}\right)$ for $24 \mathrm{~h}$. Then $1 \mathrm{ml}$ of Otto II buffer $\left(0.4 \mathrm{M} \mathrm{Na}_{2} \mathrm{HPO}_{4-}\right.$ $12 \mathrm{H}_{2} \mathrm{O}$ ), $50 \mu \mathrm{g} / \mathrm{ml}$ of propidium iodide (Sigma-Aldrich, St. Louis, MO), $50 \mu \mathrm{g} / \mathrm{ml}$ of RNase (Sigma-Aldrich, St. Louis, $\mathrm{MO})$ were added and incubated for $10 \mathrm{~min}$ at room temperature. Finally, the samples were analyzed in a (CFM) BD FACSCanto ${ }^{\mathrm{TM}}$ II (BD Biosciences, San Jose, CA, USA) flow cytometer.

Genetic stability was determined by comparing nuclear DNA content of regenerants and anther-donor plants. For that purpose, 10 regenerated plants were selected from the control group and from each pretreatment. Fourteen replicates were performed per anther-donor plant and between 4 and 6 replicates per regenerated plants. Plants were selected on different days by analyzing at least 5,000 nuclei per sample. Relative nuclear DNA content of plants was expressed via a DNA index (DI) which considered the reference standard ( $\mathrm{DI}=2 \mathrm{C}_{\text {buffel grass }} / 2 \mathrm{C}_{Z \text {. mays }}$ ). Nuclear DNA content of buffel grass was calculated using the formula:

$2 \mathrm{C}$ content of buffel grass (pg)

$$
\begin{aligned}
&= \frac{\text { Mean position of } \mathrm{G}_{0} / \mathrm{G}_{1} \text { peak of buffel grass }}{\text { Mean position of } \mathrm{G}_{0} / \mathrm{G}_{1} \text { peak of Z.mays } \mathrm{L} .} \\
& \times 5.43
\end{aligned}
$$

Statistical analysis

The number of embryogenic calli per Petri dish was determined 90 days after BAC and the proportion relative to number of cultivated explants (10 explants) was calculated. The number of seedlings was recorded throughout the regeneration period (12 months) and was expressed as the number of regenerated plants per Petri dish.

Two generalized linear models (GLMs) were fitted to evaluate the efficiency of induction and regeneration as a function of the proportion of embryogenic calli and regenerated plants, using the genotypes as fixed effects. The variable proportion of embryogenic calli (PEC) was calculated via a binomial distribution with logit link function, whereas a Poisson distribution with log link function was used to calculate the variable number of regenerated seedlings (NRS). In both cases, means between genotypes were compared with a Fisher's a posteriori test (LSD).

The best tiller collection date and treatment (control or pretreatments) for each genotype were determined by fitting the same GLMs both for PEC and NRS, with treatment, date of tiller collection and their interaction being incorporated as fixed effects. In both analyses, differences for the principal factors and their interactions were evaluated following Di Rienzo, Guzmán and Casanoves (DGC) means comparison test (Di Rienzo et al. 2002).

Genetic stability was analyzed by comparing nuclear DNA content of each regenerated plant with that of the anther-donor plant by means of a $t$ test for independent samples. The $P$ value was adjusted by the Bonferroni correction because of the high number of contrasts.

Possible effects of genotype, treatment or days under in vitro conditions (induction-regeneration-rooting) on the amount of nuclear DNA were determined by fitting a mixed model to estimate the difference between the amount of nuclear DNA of each regenerated plant and that of the anther-donor plant (considering the mean of the 14 measurements of anther-donor plants). The genotypes, treatments, days in vitro and their interactions (genotype * treatment, genotype * days in vitro, treatment * days in vitro, and genotype * treatment * days in vitro) were considered fixed effects, whereas each plant was considered random effect. All the analyses were conducted using InfoStat statistical software (Di Rienzo et al. 2012).

\section{Results}

The three apomictic genotypes of buffel grass used in this work were able to induce calli in MS medium supplemented with 2,4-D. Callus development started approximately 7 days after BAC and was manifested by the swelling of the explant tissues (Fig. 1d). Proembryos were observed at 15 of BAC and two types of calli were clearly differentiated after 30 days: non-embryogenic and embryogenic. Non-embriogenic calli had a friable appearance and were whitish and translucent (Fig. 1e), whereas embryogenic calli (Fig. 1f) were compact, white and with single or multiple undulations (somatic embryos).

Germination of embryogenic calli was observed when they were placed in the regeneration medium under light conditions. The somatic embryos first turned green and the 

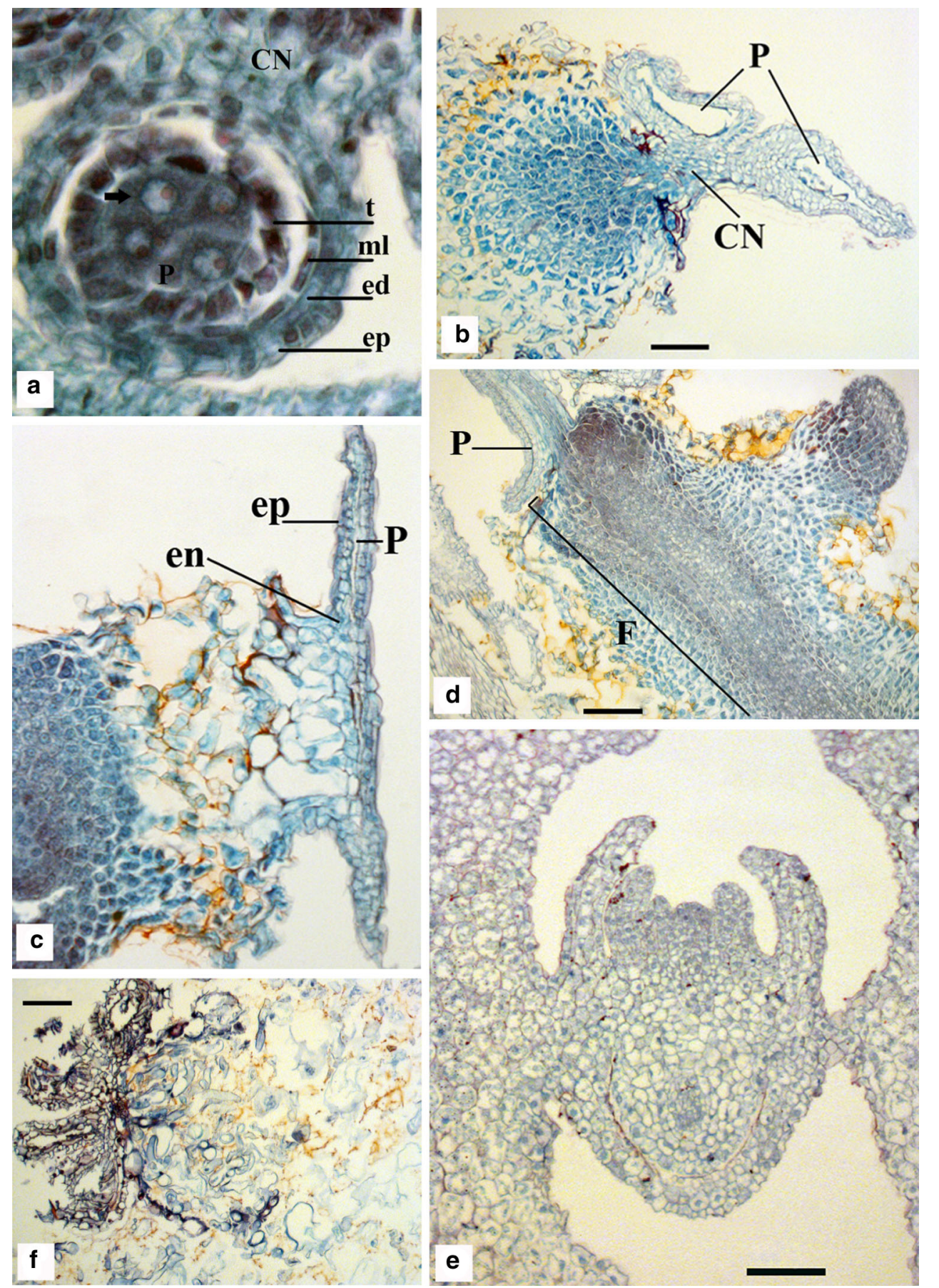

Fig. 2 Somatic embryogenesis of calli derived from in vitro anther culture in buffel grass. a Transverse section of an anther at the moment of culture, showing the pollen sac $(P)$ with uninucleate microspores (arrow), connective tissue $(C N)$ and wall cells: epidermis $(e p)$, endodermis $(e d)$, middle lamella $(m l)$ and tapetum $(t)$. b Cell

divisions from connective tissue, $\mathbf{c}$ wall and $\mathbf{d}$ anther filament after 15 days of the beginning of anther culture (BAC). e Section of an embryogenic callus showing a typical somatic embryo at 20 days after BAC. f Absence of embryogenic cells in the section of a nonembriogenic callus. Scale bar $100 \mu \mathrm{m}$

first shoots appeared on day 20 (Fig. 1g). After 4 weeks, well-developed seedlings were observed. Subculture performed at 60 days stimulated the development of new seedlings. This behavior continued for approximately 12 months, with a peak of seedling emergence at 8 months,

and then gradually declining with duration of in vitro conditions. The NRS was variable, with 1-55 seedlings being regenerated from a single embryogenic callus (Fig. 1h). Each regenerated seedling was transplanted to a pot and hardened under greenhouse conditions (Fig. 1i). 
Fig. 3 a Proportion of embryogenic calli (PEC) and b number of regenerated seedlings (NRS) from in vitro anther culture in three apomictic genotypes of buffel grass. Mean values represent three dates of tiller collection and treatments. Means with different letters are significantly different $(P \leq 0.05)$

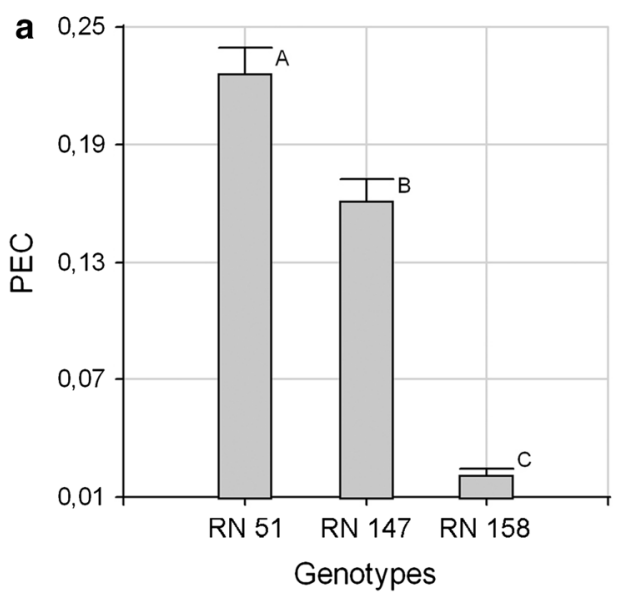

Seedling regeneration occurred only from embryogenic calli. The histological analysis confirmed that the seedlings were derived from somatic embryos and that the morphogenetic process was induced by the formation of embryos derived from somatic tissue of the stamens (Fig. 2a). Accordingly, histological sections showed areas with cellular growth in the connective tissue (Fig. 2b), wall (Fig. 2c) and anther filament (Fig. 2d). These areas are composed of small, compact, isodiametric cells with a high nucleus/ cytoplasm ratio. After 20 days of BAC, sections of embryogenic calli clearly showed the somatic embryos, which were composed of a bipolar organization (root and caulinar apices), leaf primordia and vascular system (Fig. 2f). On the other hand, friable calli did not produce somatic embryos nor did they regenerate seedlings (Fig. 2g).

The results of the GLMs showed highly significant differences among genotypes $(P<0.0001)$, both for the proportion of embryogenic calli (PEC) and the number of regenerated seedlings (NRS). The genotype RN 51 showed the best response for both variables, followed by RN 147, with RN 158 being the least efficient genotype (Fig. 3a, b).

The results of the GLMs obtained for the variables PEC and NRS performed for each genotype showed a significant interaction $(P<0.05)$ between tiller collection date * treatment, both for RN 51 and RN 147. By contrast, that interaction was not significant for either variable in the genotype RN 158 $(P>0.05)$.

In RN 51, the pretreatments applied to the tillers did not improve PEC efficiency; however, those pretreatments were beneficial for NRS on the first date of tiller collection (Table 1).

In RN 147, the efficiency of PEC was increased with the application of mannitol pretreatment on the first tiller collection date (Table 1). In addition, pretreatments promoted a higher number of regenerated seedlings both on the first and second collection dates (Table 1).

In RN 158, PEC and NRS showed highly significant differences $(\mathrm{P}<0.0001)$ in collection date, with favorable responses being observed only on the first date.
Pretreatments differed from one another $(P<0.05)$ but not from the control. Considering all of the tiller collection dates and treatments performed, this genotype produced 14 embryogenic calli and 14 regenerated plants, reason for which the results were not included in Table 1.

The FCM analysis yielded histograms with four peaks, two representing relative DNA content of buffel grass and two representing the DNA content of Z. mays L. (Fig. 4). The dominant peaks correspond to nuclei in $\mathrm{G}_{0} / \mathrm{G}_{1}$ phases, whereas the lowest peaks correspond to nuclei in $\mathrm{G}_{2}$ phase of the cell cycle. The absence of peak overlap indicates that the internal standard was adequate. Likewise, the coefficients of variation (CVs) in the $\mathrm{G}_{0} / \mathrm{G}_{1}$ phase were low. The $\mathrm{CV}$ for $Z$. mays $\mathrm{L}$. was $2.15 \pm 0.55(\mathrm{n}=432)$, whereas for buffel grass the values were $2.55 \pm 0.76(\mathrm{n}=207)$ for $\mathrm{RN} 51,2.60 \pm 0.47$ $(\mathrm{n}=225)$ for $\mathrm{RN} 147$ and $2.74 \pm 0.46(\mathrm{n}=6)$ for $\mathrm{RN} 158$. The CVs are important for the FMC analysis because they reveal quality parameters, with values below $3 \%$ generally being considered acceptable (Marie and Brown 1993).

The mean DNA index (DI) value estimated was 0.7103 for RN 51, 0.7083 for RN 147 and 0.8504 for RN 158. These indices were then used to calculate nuclear DNA content (2C value) for each genotype. Mean nuclear DNA content was $3.8568 \mathrm{pg}$ for RN 51,3.8462 pg for RN 147 and $4.6527 \mathrm{pg}$ for RN 158. These values might indicate genotypes with different ploidy levels (Burson et al. 2012; Kharrat-Souissi et al. 2012). Therefore, complementary studies, such as chromosome counting, are being conducted at our laboratory.

Table 2 shows nuclear DNA content of 93 in vitro regenerated plants derived from genotypes RN 51 and RN 147. Only three plants subjected to the 7-day water pretreatment applied to RN 51 survived in the field and were analyzed. None of the plants regenerated from genotype RN 158 survived in the field.

The results of the $t$ test for independent samples performed to determine genetic stability showed significant differences $(P<0.001)$ among nuclear DNA values (Table 2). Seven different plants were identified by the 
Table 1 Proportion of embryogenic calli (PEC) and number of regenerated seedlings (NRS) obtained from in vitro anther culture in two apomictic genotypes of buffel grass as a function of tiller collection date (TCD) and treatment (Treat.)

\begin{tabular}{|c|c|c|c|c|c|c|c|c|c|c|}
\hline \multirow[t]{3}{*}{ TCD } & \multirow[t]{3}{*}{ Treat. } & \multirow[t]{3}{*}{ Days } & \multicolumn{4}{|l|}{ RN 51} & \multicolumn{4}{|c|}{ RN 147} \\
\hline & & & \multicolumn{2}{|l|}{ PEC } & \multicolumn{2}{|l|}{ NRS } & \multicolumn{2}{|l|}{ PEC } & \multicolumn{2}{|l|}{ NRS } \\
\hline & & & Mean & $\mathrm{SE}$ & Mean & SE & Mean & SE & Mean & SE \\
\hline \multirow[t]{5}{*}{1} & Control & & 0.11 & $0.04 \mathrm{~B}$ & 4.63 & $0.76 \mathrm{C}$ & 0.07 & $0.03 \mathrm{~B}$ & 1.29 & $0.43 \mathrm{C}$ \\
\hline & Water & 5 & 0.22 & $0.05 \mathrm{~B}$ & 18.33 & $1.75 \mathrm{~A}$ & 0.13 & $0.04 \mathrm{~B}$ & 9.17 & $1.24 \mathrm{~B}$ \\
\hline & Mannitol (0.3 M) & 5 & 0.23 & $0.05 \mathrm{~B}$ & 4.5 & $0.87 \mathrm{C}$ & 0.18 & $0.05 \mathrm{~A}$ & 10.33 & $1.31 \mathrm{~B}$ \\
\hline & Water & 7 & 0.2 & $0.06 \mathrm{~B}$ & 8.8 & $1.33 \mathrm{~B}$ & 0.1 & $0.04 \mathrm{~B}$ & 1.67 & $0.53 \mathrm{C}$ \\
\hline & Mannitol (0.3 M) & 7 & 0.13 & $0.04 \mathrm{~B}$ & 14.83 & $1.57 \mathrm{~A}$ & 0.2 & $0.06 \mathrm{~A}$ & 8.6 & $1.31 \mathrm{~B}$ \\
\hline \multirow[t]{5}{*}{2} & Control & & 0.44 & $0.06 \mathrm{~A}$ & 20.71 & $1.72 \mathrm{~A}$ & 0.21 & $0.05 \mathrm{~A}$ & 6.38 & $0.89 \mathrm{~B}$ \\
\hline & Water & 5 & 0.25 & $0.06 \mathrm{~B}$ & 17.33 & $1.7 \mathrm{~A}$ & 0.28 & $0.06 \mathrm{~A}$ & 14.33 & $1.55 \mathrm{~A}$ \\
\hline & Mannitol (0.3 M) & 5 & 0.3 & $0.06 \mathrm{~A}$ & 19 & $1.78 \mathrm{~A}$ & 0.37 & $0.06 \mathrm{~A}$ & 17 & $1.68 \mathrm{~A}$ \\
\hline & Water & 7 & 0.12 & $0.04 \mathrm{~B}$ & 4.83 & $0.9 \mathrm{C}$ & 0.22 & $0.05 \mathrm{~A}$ & 15.5 & $1.61 \mathrm{~A}$ \\
\hline & Mannitol & 7 & 0.35 & $0.06 \mathrm{~A}$ & 10.5 & $1.32 \mathrm{~B}$ & 0.18 & $0.05 \mathrm{~A}$ & 12.17 & $1.42 \mathrm{~A}$ \\
\hline \multirow[t]{5}{*}{3} & Control & & 0.36 & $0.05 \mathrm{~A}$ & 17.75 & $1.49 \mathrm{~A}$ & 0.17 & $0.05 \mathrm{~A}$ & 8.43 & $1.1 \mathrm{~B}$ \\
\hline & Water & 5 & 0.18 & $0.05 \mathrm{~B}$ & 5.83 & $0.99 \mathrm{C}$ & 0.08 & $0.04 \mathrm{~B}$ & 0.33 & $0.24 \mathrm{C}$ \\
\hline & Mannitol (0.3 M) & 5 & 0.2 & $0.05 \mathrm{~B}$ & 3.17 & $0.73 \mathrm{C}$ & 0.07 & $0.03 \mathrm{~B}$ & 0.00 & $0.00 \mathrm{C}$ \\
\hline & Water & 7 & 0.13 & $0.04 \mathrm{~B}$ & 0.83 & $0.37 \mathrm{D}$ & 0.12 & $0.04 \mathrm{~B}$ & 1.67 & $0.53 \mathrm{C}$ \\
\hline & Mannitol (0.3 M) & 7 & 0.15 & $0.05 \mathrm{~B}$ & 4.83 & $0.9 \mathrm{C}$ & 0.03 & $0.02 \mathrm{~B}$ & 0.00 & $0.00 \mathrm{C}$ \\
\hline
\end{tabular}

Means with different letters within each column are significantly different $(P \leq 0.05)$

comparisons made in genotype RN 51 (43), with five having a lower DNA content and two having a higher one (Table 2). In the five plants with lower nuclear DNA content, the range of variation in $2 \mathrm{C}$ content was between $3.7291 \mathrm{pg}$ and $3.7959 \mathrm{pg}$, representing $3.31-1.6 \%$ of variation of the anther-donor plant, respectively. In the two plants with higher nuclear DNA content (Table 2), 2C values represented approximately double of the cytotype from which they were derived. The comparisons made in the plants regenerated from genotype RN 147 (50) did not show an increase in nuclear DNA content; however, three plants with lower content were detected (Table 2). The percentage of variation of nuclear DNA content of these plants with respect to the genotype of origin was between 3.16 and $2.62 \%$.

The model analyzing the influence of the genotype, treatments or days in vitro on the amount of nuclear DNA show no significant effect for any of the principal factors [genotype $(P=0.4993)$, treatment $(P=0.5082)$, days in vitro $(P=0.4051)$ ] or for any of their interactions [treatments $*$ days in vitro $(P=0.1926)$, treatment $*$ genotype $(P=0.2203)$, genotype $*$ days in vitro $(P=0.3884)$ and genotype $*$ treatments $*$ days in vitro $(P=0.2203)$.

\section{Discussion}

A protocol for whole plant regeneration via somatic embryogenesis was fine-tuned using anthers with uninucleate microspores as explants in three apomictic genotypes of buffel grass. The somatic embryos were induced in MS medium (Murashige and Skoog 1962) supplemented with 2,4-D, as previously performed in mature embryos and inflorescences (Kackar and Shekhawat 1991; Colomba et al. 2006; Yadav et al. 2009). The somatic embryos showed size and shape characteristics similar to those observed for the species (Yadav et al. 2009). Likewise, these embryos germinated when exposed to light in a medium with low auxin and cytokinin concentrations (Colomba et al. 2006). Therefore, anthers can be used as an alternative explant to mature embryos, inflorescences, seeds (Ross et al. 1995; Bhat et al. 2001) and apical shoots (Yadav et al. 2009; Kumar and Bhat 2012), for regenerating plants in buffel grass tissue culture.

Histological sections showed that somatic cells of anthers produced somatic embryos. Indeed, the great totipotency of these cells to induce somatic embryogenesis is well known (Perrin et al. 2004; Chen et al. 2005; Rodrigues et al. 2005; Salas et al. 2011). For example, histological sections showed proembryos derived from a cell mass that proliferated from the connective tissue and filament, as described in V. vinifera (Faure et al. 1996; Perrin et al. 2004). The cells of the anther wall have also been mentioned as responsible for initiating the morphogenetic process (Niimi et al. 2001; Chen et al. 2005; Rodrigues et al. 2005; Parra-Vega et al. 2012). The sections analyzed also exhibited strong cellular divisions near the endothecium, suggesting the involvement of this cell layer in the process. On the other hand, no induced microspores were 

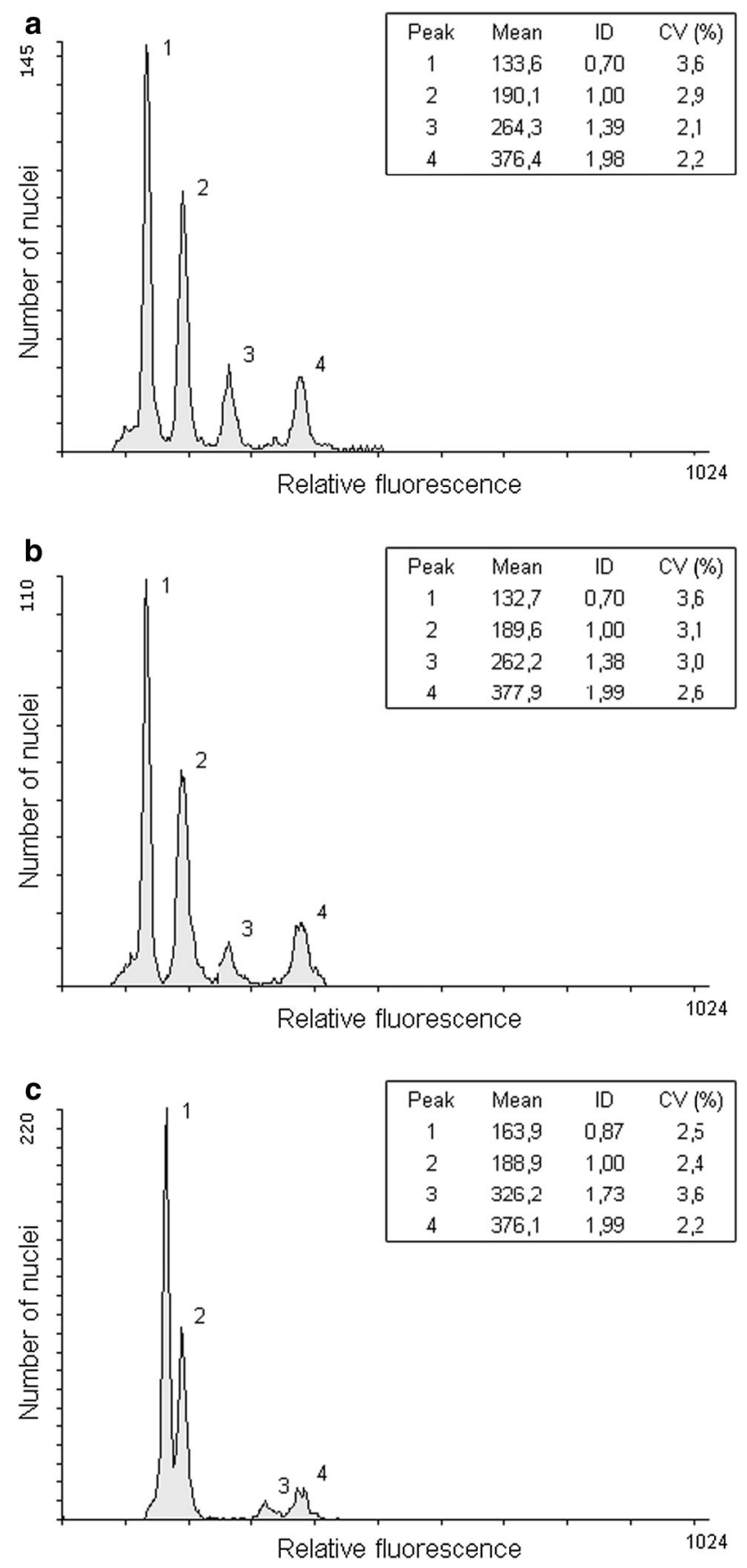

Fig. 4 Histograms of relative fluorescence intensity obtained with the simultaneous analysis of isolated nuclei of leaves of buffel grass and Zea mays CE-777 ( $2 \mathrm{C}=5.43 \mathrm{pg} \mathrm{DNA})$ as a reference standard. Genotypes a RN 51, b RN 147 and c RN 158. Peaks 1 and 2 correspond to nuclei in the $\mathrm{G}_{0} / \mathrm{G}_{1}$ phase of buffel grass (1) and of Zea mays (2), whereas peaks 3 and 4 correspond to nuclei in the G2 phase of buffel grass (3) and of Zea mays (4)

observed, which is in agreement with studies conducted in V. vinifera (Faure et al. 1996) in that that microspores are reabsorbed or degenerated and do not participate in embryo formation. Therefore, these observations clearly show that embryogenic calli, and consequently regenerated plants, are of somatic origin.

The results obtained indicate that, under the same experimental conditions, the three apomictic genotypes of buffel grass responded to in vitro anther culture, but differed in their efficiency both for embryogenic callus induction and plant regeneration. These observations would confirm the genotype effect on in vitro culture in this species, because the same responses were observed when mature embryos or inflorescences were used as explant (Colomba et al. 2006; Yadav et al. 2009).

The greatest responses of embryogenic callus induction were observed in the genotype RN $51(44 \%)$ and were similar to those reported in buffel grass by Ross et al. (1995) for seeds (30\%) and by Yadav et al. (2009) for inflorescences $(33.6 \%)$. These results are different from those reported by Colomba et al. (2006), who obtained $83 \%$ induction using mature embryo, but a lower number of regenerated plants than the values we found using anther explant. Considering that those authors used the same genotype and induction conditions (Colomba et al. 2006) as in this work, the differences observed may be due to the explant used. Accordingly, taking into account the greater totipotency of the young tissues of inflorescences (Benkirane et al. 2000; Vikrant and Rashid 2002; Jha et al. 2009) and that buffel grass has a positive correlation between the number of somatic embryos formed and the number of regenerated plants (Colomba et al. 2006), anthers are likely to induce a higher number of somatic embryos per embryogenic callus than the other explants. Another explanation might be a greater germination of somatic embryos formed due to auxin concentration included at the regeneration stage (Lambé et al. 1999), because Colomba et al. (2006) used $0.1 \mathrm{mg} / \mathrm{l}$ NAA versus the $0.5 \mathrm{mg} / \mathrm{l}$ used in this work.

The information obtained in this work suggests that the pretreatments applied to tillers promote embryogenic competition of somatic cells on some tiller collection dates. The stimulus was similar to that observed in the in vitro anther culture for obtaining doubled-haploids (Cistué et al. 1999; Kruczkowska et al. 2002). The use of 0.3 M mannitol at $4{ }^{\circ} \mathrm{C}$ during 5 or 7 days improved the embryogenic response in PI 147 (first collection date), as mentioned for microspore culture in wheat (Labbani et al. 2007). In addition, in RN 147 (first and second collection date) and RN 51 (first collection date), pretreatment induced a higher number of regenerated seedlings. Thus, pretreatment effect would be related to the induction period, when the different stresses applied to anthers are likely to generate a higher number of somatic embryos per induced embryogenic callus (Kruczkowska et al. 2002).

Another similarity observed with the use of in vitro anther culture for obtaining doubled-haploids is that tiller collection date affected the response to induction and 
Table 2 2C nuclear DNA determined by flow cytometry of plants regenerated by in vitro anther culture from two apomictic genotypes of buffel grass

\begin{tabular}{|c|c|c|c|c|c|c|c|c|c|}
\hline \multicolumn{5}{|c|}{ RN 51} & \multicolumn{5}{|c|}{ RN 147} \\
\hline Plant & $\mathrm{T}$ & $2 \mathrm{C}(\mathrm{pg})$ & $\mathrm{n}$ & $\mathrm{CV} \pm \mathrm{SD}$ & Plant & $\mathrm{T}$ & $2 \mathrm{C}(\mathrm{pg})$ & $\mathrm{n}$ & $\mathrm{CV} \pm \mathrm{SD}$ \\
\hline Pl.1 & Control & 3.8192 & 6 & $2.47 \pm 0.34$ & Pl.1 & Control & 3.7882 & 4 & $3.15 \pm 0.44$ \\
\hline Pl.2 & Control & 3.8239 & 4 & $2.32 \pm 0.48$ & $\mathrm{Pl} .2$ & Control & 3.8222 & 4 & $2.89 \pm 0.31$ \\
\hline Pl.3 & Control & 3.8307 & 4 & $1.84 \pm 0.85$ & $\mathrm{Pl} .3$ & Control & 3.8068 & 4 & $2.21 \pm 0.31$ \\
\hline Pl.4 & Control & 3.8526 & 4 & $2.92 \pm 0.17$ & $\mathrm{Pl} .4$ & Control & 3.8357 & 4 & $3.01 \pm 0.27$ \\
\hline Pl.5 & Control & 3.8020 & 4 & $2.73 \pm 0.15$ & $\mathrm{P} 1.5$ & Control & 3.8325 & 4 & $2.89 \pm 0.06$ \\
\hline Pl.6 & Control & $3.7322^{*}$ & 6 & $2.03 \pm 0.21$ & Pl.6 & Control & 3.8337 & 4 & $2.10 \pm 0.10$ \\
\hline Pl.7 & Control & $3.7625^{*}$ & 6 & $2.39 \pm 0.19$ & $\mathrm{Pl} .7$ & Control & 3.8509 & 4 & $2.44 \pm 0.41$ \\
\hline Pl.8 & Control & 3.8226 & 4 & $1.84 \pm 1.00$ & $\mathrm{Pl} .8$ & Control & 3.8229 & 4 & $2.18 \pm 0.23$ \\
\hline Pl.9 & Control & 3.7948 & 4 & $2.73 \pm 0.24$ & Pl.9 & Control & 3.8159 & 4 & $3.00 \pm 0.20$ \\
\hline Pl.10 & Control & 3.8208 & 4 & $3.00 \pm 0.23$ & Pl.10 & Control & 3.8282 & 4 & $2.90 \pm 0.12$ \\
\hline Pl.1 & $\mathrm{H}_{2} \mathrm{O} 5 \mathrm{~d}$ & 3.8096 & 4 & $2.90 \pm 0.15$ & Pl.1 & $\mathrm{H}_{2} \mathrm{O} 5 \mathrm{~d}$ & 3.8557 & 4 & $2.99 \pm 0.31$ \\
\hline Pl.2 & $\mathrm{H}_{2} \mathrm{O} 5 \mathrm{~d}$ & 3.8159 & 4 & $1.75 \pm 0.79$ & $\mathrm{Pl} .2$ & $\mathrm{H}_{2} \mathrm{O} 5 \mathrm{~d}$ & 3.8094 & 4 & $2.11 \pm 0.45$ \\
\hline Pl.3 & $\mathrm{H}_{2} \mathrm{O} 5 \mathrm{~d}$ & 3.8425 & 4 & $1.93 \pm 0.99$ & $\mathrm{Pl} .3$ & $\mathrm{H}_{2} \mathrm{O} 5 \mathrm{~d}$ & 3.8004 & 4 & $2.29 \pm 0.25$ \\
\hline Pl.4 & $\mathrm{H}_{2} \mathrm{O} 5 \mathrm{~d}$ & $3.7291^{*}$ & 6 & $1.94 \pm 0.19$ & $\mathrm{Pl} .4$ & $\mathrm{H}_{2} \mathrm{O} 5 \mathrm{~d}$ & 3.8289 & 4 & $2.57 \pm 0.09$ \\
\hline Pl.5 & $\mathrm{H}_{2} \mathrm{O} 5 \mathrm{~d}$ & 3.8092 & 6 & $2.62 \pm 0.09$ & $\mathrm{Pl} .5$ & $\mathrm{H}_{2} \mathrm{O} 5 \mathrm{~d}$ & 3.8273 & 4 & $2.24 \pm 0.32$ \\
\hline Pl.6 & $\mathrm{H}_{2} \mathrm{O} 5 \mathrm{~d}$ & $3.7322^{*}$ & 6 & $2.24 \pm 0.23$ & Pl.6 & $\mathrm{H}_{2} \mathrm{O} 5 \mathrm{~d}$ & 3.8619 & 4 & $3.14 \pm 0.56$ \\
\hline Pl.7 & $\mathrm{H}_{2} \mathrm{O} 5 \mathrm{~d}$ & 3.8615 & 4 & $2.46 \pm 0.33$ & $\mathrm{Pl} .7$ & $\mathrm{H}_{2} \mathrm{O} 5 \mathrm{~d}$ & 3.8250 & 4 & $2.84 \pm 0.42$ \\
\hline Pl.8 & $\mathrm{H}_{2} \mathrm{O} 5 \mathrm{~d}$ & 3.8107 & 4 & $2.90 \pm 0.11$ & Pl.8 & $\mathrm{H}_{2} \mathrm{O} 5 \mathrm{~d}$ & 3.8494 & 4 & $2.57 \pm 0.05$ \\
\hline Pl.9 & $\mathrm{H}_{2} \mathrm{O} 5 \mathrm{~d}$ & 3.8074 & 4 & $3.00 \pm 0.18$ & Pl.9 & $\mathrm{H}_{2} \mathrm{O} 5 \mathrm{~d}$ & 3.8124 & 4 & $2.63 \pm 0.16$ \\
\hline Pl.10 & $\mathrm{H}_{2} \mathrm{O} 5 \mathrm{~d}$ & 3.7984 & 4 & $2.90 \pm 0.09$ & Pl.10 & $\mathrm{H}_{2} \mathrm{O} 5 \mathrm{~d}$ & 3.8563 & 4 & $2.71 \pm 0.18$ \\
\hline Pl.1 & $0.3 \mathrm{M} 5 \mathrm{~d}$ & $7.3995^{*}$ & 6 & $1.69 \pm 0.25$ & Pl.1 & $0.3 \mathrm{M} 5 \mathrm{~d}$ & 3.8232 & 4 & $2.62 \pm 0.22$ \\
\hline $\mathrm{Pl} .2$ & $0.3 \mathrm{M} 5 \mathrm{~d}$ & $7.3770^{*}$ & 7 & $1.87 \pm 0.23$ & $\mathrm{Pl} .2$ & $0.3 \mathrm{M} 5 \mathrm{~d}$ & 3.8304 & 4 & $2.64 \pm 0.08$ \\
\hline $\mathrm{Pl} .3$ & $0.3 \mathrm{M} 5 \mathrm{~d}$ & 3.8223 & 4 & $3.38 \pm 0.64$ & $\mathrm{Pl} .3$ & $0.3 \mathrm{M} 5 \mathrm{~d}$ & 3.8344 & 4 & $2.79 \pm 0.08$ \\
\hline Pl.4 & $0.3 \mathrm{M} 5 \mathrm{~d}$ & 3.7225 & 4 & $3.60 \pm 0.75$ & $\mathrm{Pl} .4$ & $0.3 \mathrm{M} 5 \mathrm{~d}$ & 3.8306 & 4 & $2.28 \pm 0.21$ \\
\hline Pl.5 & $0.3 \mathrm{M} 5 \mathrm{~d}$ & 3.8029 & 4 & $3.50 \pm 0.53$ & $\mathrm{Pl} .5$ & $0.3 \mathrm{M} 5 \mathrm{~d}$ & 3.7984 & 4 & $2.94 \pm 0.64$ \\
\hline Pl.6 & $0.3 \mathrm{M} 5 \mathrm{~d}$ & 3.8062 & 4 & $3.34 \pm 0.47$ & Pl.6 & $0.3 \mathrm{M} 5 \mathrm{~d}$ & 3.8225 & 4 & $2.77 \pm 0.10$ \\
\hline Pl.7 & $0.3 \mathrm{M} 5 \mathrm{~d}$ & 3.8274 & 4 & $3.43 \pm 0.61$ & $\mathrm{Pl} .7$ & $0.3 \mathrm{M} 5 \mathrm{~d}$ & 3.8251 & 4 & $2.25 \pm 0.05$ \\
\hline Pl.8 & $0.3 \mathrm{M} 5 \mathrm{~d}$ & 3.8139 & 4 & $1.80 \pm 0.31$ & $\mathrm{Pl} .8$ & $0.3 \mathrm{M} 5 \mathrm{~d}$ & 3.8164 & 4 & $2.22 \pm 0.10$ \\
\hline Pl.9 & $0.3 \mathrm{M} 5 \mathrm{~d}$ & $3.7536^{*}$ & 6 & $1.78 \pm 0.19$ & Pl.9 & $0.3 \mathrm{M} 5 \mathrm{~d}$ & 3.8205 & 4 & $2.74 \pm 0.28$ \\
\hline Pl.10 & $0.3 \mathrm{M} 5 \mathrm{~d}$ & 3.8277 & 4 & $2.37 \pm 0.32$ & $\mathrm{Pl} .10$ & $0.3 \mathrm{M} 5 \mathrm{~d}$ & 3.8199 & 4 & $2.18 \pm 0.13$ \\
\hline Pl.1 & $\mathrm{H}_{2} \mathrm{O} 7 \mathrm{~d}$ & 3.8417 & 4 & $3.17 \pm 0.20$ & Pl.1 & $\mathrm{H}_{2} \mathrm{O} 7 \mathrm{~d}$ & 3.8294 & 4 & $2.85 \pm 0.17$ \\
\hline Pl.2 & $\mathrm{H}_{2} \mathrm{O} 7 \mathrm{~d}$ & 3.8130 & 4 & $2.94 \pm 0.16$ & $\mathrm{Pl} .2$ & $\mathrm{H}_{2} \mathrm{O} 7 \mathrm{~d}$ & 3.8049 & 4 & $1.89 \pm 0.24$ \\
\hline Pl.3 & $\mathrm{H}_{2} \mathrm{O} 7 \mathrm{~d}$ & 3.8166 & 4 & $3.09 \pm 0.30$ & $\mathrm{Pl} .3$ & $\mathrm{H}_{2} \mathrm{O} 7 \mathrm{~d}$ & 3.8001 & 4 & $2.39 \pm 0.48$ \\
\hline Pl.1 & $0.3 \mathrm{M} 7 \mathrm{~d}$ & 3.8139 & 4 & $1.69 \pm 1.09$ & $\mathrm{Pl} .4$ & $\mathrm{H}_{2} \mathrm{O} 7 \mathrm{~d}$ & 3.8155 & 4 & $2.05 \pm 0.04$ \\
\hline $\mathrm{Pl} .2$ & $0.3 \mathrm{M} 7 \mathrm{~d}$ & 3.8242 & 4 & $3.09 \pm 0.34$ & $\mathrm{Pl} .5$ & $\mathrm{H}_{2} \mathrm{O} 7 \mathrm{~d}$ & 3.8636 & 3 & $2.57 \pm 0.42$ \\
\hline Pl.3 & $0.3 \mathrm{M} 7 \mathrm{~d}$ & 3.7888 & 4 & $2.56 \pm 0.08$ & Pl.6 & $\mathrm{H}_{2} \mathrm{O} 7 \mathrm{~d}$ & 3.8394 & 4 & $3.22 \pm 0.20$ \\
\hline Pl.4 & $0.3 \mathrm{M} 7 \mathrm{~d}$ & 3.8329 & 4 & $2.09 \pm 0.46$ & Pl.7 & $\mathrm{H}_{2} \mathrm{O} 7 \mathrm{~d}$ & $3.7420^{*}$ & 6 & $3.20 \pm 0.14$ \\
\hline Pl.5 & $0.3 \mathrm{M} 7 \mathrm{~d}$ & 3.8595 & 4 & $2.28 \pm 0.38$ & Pl. 8 & $\mathrm{H}_{2} \mathrm{O} 7 \mathrm{~d}$ & $3.7457 *$ & 6 & $3.00 \pm 0.14$ \\
\hline Pl.6 & $0.3 \mathrm{M} 7 \mathrm{~d}$ & 3.8528 & 4 & $2.93 \pm 0.09$ & Pl.9 & $\mathrm{H}_{2} \mathrm{O} 7 \mathrm{~d}$ & 3.8184 & 4 & $2.91 \pm 0.10$ \\
\hline Pl.7 & $0.3 \mathrm{M} 7 \mathrm{~d}$ & 3.8256 & 4 & $2.59 \pm 0.24$ & $\mathrm{Pl} .10$ & $\mathrm{H}_{2} \mathrm{O} 7 \mathrm{~d}$ & 3.8139 & 4 & $2.90 \pm 0.13$ \\
\hline Pl.8 & $0.3 \mathrm{M} 7 \mathrm{~d}$ & 3.8103 & 4 & $2.60 \pm 0.26$ & Pl.1 & $0.3 \mathrm{M} 7 \mathrm{~d}$ & 3.7884 & 4 & $3.05 \pm 0.74$ \\
\hline Pl.9 & $0.3 \mathrm{M} 7 \mathrm{~d}$ & 3.8304 & 4 & $2.53 \pm 0.17$ & $\mathrm{Pl} .2$ & $0.3 \mathrm{M} 7 \mathrm{~d}$ & 3.8363 & 4 & $2.37 \pm 0.56$ \\
\hline \multirow[t]{4}{*}{ Pl.10 } & $0.3 \mathrm{M} 7 \mathrm{~d}$ & 3.8437 & 4 & $3.04 \pm 0.27$ & $\mathrm{Pl} .3$ & $0.3 \mathrm{M} 7 \mathrm{~d}$ & 3.8071 & 4 & $2.92 \pm 0.38$ \\
\hline & & & & & $\mathrm{Pl} .4$ & $0.3 \mathrm{M} 7 \mathrm{~d}$ & 3.8812 & 4 & $1.96 \pm 0.10$ \\
\hline & & & & & $\mathrm{P} 1.5$ & $0.3 \mathrm{M} 7 \mathrm{~d}$ & 3.8390 & 4 & $2.12 \pm 0.25$ \\
\hline & & & & & Pl.6 & $0.3 \mathrm{M} 7 \mathrm{~d}$ & $3.7246^{*}$ & 6 & $2.84 \pm 0.14$ \\
\hline
\end{tabular}


Table 2 continued

\begin{tabular}{|c|c|c|c|c|c|c|c|c|c|}
\hline \multicolumn{5}{|c|}{ RN 51} & \multicolumn{5}{|c|}{ RN 147} \\
\hline Plant & $\mathrm{T}$ & $2 \mathrm{C}(\mathrm{pg})$ & $\mathrm{n}$ & $\mathrm{CV} \pm \mathrm{SD}$ & Plant & $\mathrm{T}$ & $2 \mathrm{C}(\mathrm{pg})$ & $\mathrm{n}$ & $\mathrm{CV} \pm \mathrm{SD}$ \\
\hline & & & & & Pl.7 & $0.3 \mathrm{M} 7 \mathrm{~d}$ & 3.8432 & 4 & $2.03 \pm 0.15$ \\
\hline & & & & & Pl.8 & $0.3 \mathrm{M} 7 \mathrm{~d}$ & 3.8475 & 6 & $2.50 \pm 0.25$ \\
\hline & & & & & Pl.9 & $0.3 \mathrm{M} 7 \mathrm{~d}$ & 3.8339 & 4 & $2.44 \pm 0.50$ \\
\hline & & & & & Pl.10 & $0.3 \mathrm{M} 7 \mathrm{~d}$ & 3.8388 & 4 & $2.11 \pm 0.28$ \\
\hline
\end{tabular}

The $2 \mathrm{C}$ value is the mean number of times that the sample was analyzed (n) and is expressed in picograms (pg), which were obtained by analyzing the whole set of isolated nuclei of buffel grass and Zea mays CE-777 (2C $=5.43 \mathrm{pg}$ DNA) as a reference standard

* Significant differences in $2 \mathrm{C}$ content between the in vitro regenerated plant and the anther-donor plant

The CV mean and standard deviation $(C V \pm S D)$ of the fluorescence intensity of the nuclei in the $\mathrm{G}_{0} / \mathrm{G}_{1}$ phase of buffel grass is provided. (T) Control + pretreatments: distilled water for 5 and 7 days, $\left(\mathrm{H}_{2} \mathrm{O} 5 \mathrm{~d}\right.$ and $\mathrm{H}_{2} \mathrm{O} 7 \mathrm{~d}$, respectively), and $0.3 \mathrm{M}$ Mannitol for 5 and 7 days $(0.3 \mathrm{M} 5 \mathrm{~d}$ and $0.3 \mathrm{M} 7 \mathrm{~d}$, respectively)

regeneration. In RN 158, the first tillers exhibited a better embryogenic response, whereas the best responses for RN 51 and RN 147 (without pretreatment application) were obtained when the plants reached full flowering (second and third collection date). This behavior may be related to physiological conditions of the donor plant, since they are known to influence embryogenic response (Dunwell 1976, Takahata et al. 1991). Ercan et al. (2006) suggested that, for in vitro anther culture, inflorescences from plants that are under the best development states should be collected. Hence, because Cenchrus spp. have different growth patterns (Hanselka et al. 2004) and the embryogenic response depends on the genotype, RN 158 is likely to reach the maximum embryogenic potential on earlier dates, whereas this phenomenon may happen on later dates for RN 51 or RN 147. This behavior would facilitate the harvest of inflorescences on different dates during the growing season, which would allow us to obtain the maximum embryogenic potential for each genotype.

FCM analyses performed in in vitro regenerated plants revealed variations in nuclear DNA content. These results suggest genetic instability in some plants regenerated via somatic embryogenesis. The detection of plants with lower nuclear DNA content values suggests the existence of DNA aneuploid plants (Jin et al. 2008). This assumption is based on the fact that many of the changes that can be detected by FCM are associated with variations in the number of chromosomes (Clarindo et al. 2008; Currais et al. 2013). Here we detected decreases in nuclear DNA content in regenerated plants with respect to anther donor plants in RN 51 (3.31-1.6\%) and RN 147 (3.16-2.6\%). These variations might be enough to indicate the complete or partial loss of a chromosome (Pfosser et al. 1995; Roux et al. 2003).

Furthermore, FCM studies allowed us to detect plants with values of nearly twice the nuclear DNA content, suggesting a possible in vitro polyploidization (Barow and
Jovtchev 2007). The increase in DNA ploidy level is a variation frequently observed during somatic embryogenesis; however, it is difficult to attribute this phenomenon to a single factor (May and Sink 1995; Tremblay et al. 1999; Endemann et al. 2001; Lim and Loh 2003; Clarindo et al. 2008; Jin et al. 2008). In the present study, the increase in nuclear DNA content was observed only in two RN 51 plants derived from tillers whose stems had been immersed in mannitol for 5 days, but this phenomenon was not detected in plants of the remaining pretreatments. The percentage of polyploidization was $4.7 \%$ of all plants analyzed, which is consistent with polyploidization values found via somatic embryogenesis for other species (Kubaláková et al. 1996; Endemann et al. 2001; Leal et al. 2006; Prado et al. 2010). Hence, because there was no significant effect in the modification of nuclear DNA content with respect to pretreatment, we consider that the stresses applied to tillers might not be responsible for polyploidization.

While genotype or days in vitro are factors that favor the frequency of appearance of DNA polyploid plants or even DNA aneuploids (Tremblay et al. 1999; Endemann et al. 2001; Currais et al. 2013), we did not find an association with any of these factors or with the pretreatments analyzed. Therefore, the changes observed in nuclear DNA content might be caused by the effect of growth regulators used in the culture media. We consider that synthetic auxin 2,4-D might be involved, because it was found to be a factor favoring changes in the genome of in vitro regenerated plants (May and Sink 1995; Jin et al. 2008; Clarindo et al. 2008). Additional assays would be useful to confirm the possible role of 2,4-D as a factor promoting the variations observed, as well as NAA or BAP, which were also mentioned as possible mutagenic agents ( $\mathrm{Lim}$ and Loh 2003; Mishiba et al. 2006; Barow and Jovtchev 2007).

This work demonstrates the capacity of anthers of the three buffel grass apomictic genotypes to regenerate plants 
via somatic embryogenesis, suggesting the potential of this explant type for use in genotypes of this species. An important aspect to consider is the percentage of regenerated plants that express variations with respect to the genotype of origin, which were easily detected by FCM. In buffel grass apomictic genotypes, somaclonal variation would provide an opportunity to obtain new genotypes that might be included as sources of genetic variability in breeding programs. Works are being conducted focusing on regenerated RN 51 plants that exhibited lowest nuclear DNA content.

Acknowledgments We are grateful to Jaroslav Dolezel for providing the plant DNA standards used in this work. We thank P. Crespo and P. Abadie for assistance with the FCM analysis and I. Teich for assistance with statistical analyses. This research was supported by the projects INTA-AEFP-PE No. 261821 and CONICET (PIP 112201101 0031).

\section{References}

Barow M, Jovtchev G (2007) Endopolyploidy in plants and its analysis by flow cytometry. In: Dolezel J, Greilhuber J, Suda J (eds) Flow cytometry with plant cells. Wiley, Weinheim, pp 349-372

Benkirane H, Sabounji K, Chlyah A, Chlyah H (2000) Somatic embryogenesis and plant regeneration from fragments of immature inflorescences and coleoptiles of durum wheat. Plant Cell Tissue Organ Cult 61:107-113

Bhat V, Dalton SJ, Kumar S, Bhat BV, Gupta MG, Morris P (2001) Particle-inflow-gun-mediated genetic transformation of buffel grass (Cenchrus ciliaris L.): optimizing biological and physical parameters. J Appl Genet 42:405-412

Burson BL, Actkinson JM, Hussey MA, Jessup RW (2012) Ploidy determination of buffel grass accessions in the USDA National Plant Germplasm System collection by flow cytometry. S Afr J Bot 79:91-95

Chen LJ, Zhu XY, Gu L, Wu J (2005) Efficient callus induction and plant regeneration from anther of Chinese narcissus (Narcissus tazetta L. var. chinensis Roem). Plant Cell Rep 24:401-407

Cistué L, Ramos A, Castillo AM (1999) Influence of anther pretreatment and culture medium composition on the production of barley doubled haploids from model and low responding cultivars. Plant Cell Tissue Organ Cult 55:159-166

Clarindo WR, de Carvalho CR, Araújo FS, de Abreu IS, Otoni WC (2008) Recovering polyploid papaya in vitro regenerants as screened by flow cytometry. Plant Cell Tissue Organ Cult 92:207-214

Colomba EL, Grunberg K, Griffa S, Ribotta A, Mroginski L, Biderbost E (2006) The effect of genotype and culture medium on somatic embryogenesis and plant regeneration from mature embryos of fourteen apomictic cultivars of buffel grass (Cenchrus ciliaris L.). Grass Forage Sci 61:2-8

Currais L, Loureiro J, Santos C, Canhoto JM (2013) Ploidy stability in embryogenic cultures and regenerated plantlets of tamarillo. Plant Cell Tissue Organ Cult 114:149-159

D’Ambrogio de Argüeso A (1986) Manual de Técnicas en Histología Vegetal. Hemisferio Sur S.A, Buenos Aires

Di Rienzo JA, Guzmán AW, Casanoves F (2002) A multiple comparisons method based on the distribution of the root node distance of a binary tree. J Agric Biol Environ Stat 7:1-14
Di Rienzo JA, Casanoves F Balzarini MG, Gonzalez L, Tablada M, Robledo CW (2012) InfoStat. Grupo InfoStat, FCA, Universidad Nacional de Córdoba, Argentina. http://www.infostat.com.ar

Doležel J, Greilhuber J, Suda J (2007) Estimation of nuclear DNA content in plants using flow cytometry. Nat Protoc 2:2233-2244

Dunwell JM (1976) A comparative study of environmental and developmental factors which influence embryo induction and growth in cultured anthers of Nicotiana Tabacum. Environ Exp Bot 16:109-118

Endemann M, Hristoforoglu K, Stauber T, Wilhelm E (2001) Assessment of age-related polyploidy in Quercus robur L. somatic embryos and regenerated plants using DNA flow cytometry. Biol Plant 44:339-345

Ercan N, Sensoy AF, Sensoy AS (2006) Influence of growing season and donor plant age on anther culture response of some pepper cultivars (Capsicum annuum L.). Sci Hortic 110:16-20

Faure O, Aarrouf J, Nougarède A (1996) Ontogenesis, differentiation and precocious germination in anther-derived somatic embryos of grapevine (Vitis vinifera L.): proembryogenesis. Ann Bot 78:23-28

Fisher WD, Bashaw EC, Holt EC (1954) Evidence of apomixis in Pennisetum ciliare and Cenchrus setigerus. Agron $\mathbf{J}$ 46:401-404

Hanna WW, Bashaw EC (1987) Apomixis: its identification and use in plant breeding. Crop Sci 27:1136-1139

Hanselka CW, Hussey MA, Ibarra F (2004) Buffelgrass. In: Moser LE, Burson BL, Sollenberger LE (eds) Warm-season $\left(\mathrm{C}_{4}\right)$ grasses. Madison, Wisconsin, pp 477-502

Jain SM (2001) Tissue culture-derived variation in crop improvement. Euphytica 118:153-166

Jessup RW, Burson BL, Burow O, Wang YW, Chang C, Li Z, Paterson AH, Hussey MA (2003) Segmental allotetraploidy and allelic interactions in buffelgrass (Pennisetum ciliare (L.) Link syn. Cenchrus ciliaris L.) as revealed by genome mapping. Genome 46:304-313

Jha P, Yadav CB, Anjaiah V, Bhat V (2009) In vitro plant regeneration through somatic embryogenesis and direct shoot organogenesis in Pennisetum glaucum (L.) R. Br. In Vitro Cell Dev Biol Plant 45:145-154

Jin S, Mushke R, Zhu H, Tu L, Lin Z, Zhang Y, Zhang X (2008) Detection of somaclonal variation of cotton (Gossypium hirsutum) using cytogenetics, flow cytometry and molecular markers. Plant Cell Rep 27(8):1303-1316

Kackar A, Shekhawat NS (1991) Plant regeneration from cultured immature inflorescences of Cenchrus setigerus and Cenchrus ciliaris. Indian J Exp Biol 29:62-64

Kharrat-Souissi A, Siljak-Yakovlev S, Brown SC, Chaieb M (2012) Cytogeography of Cenchrus ciliaris (Poaceae) in Tunisia. Folia Geobot 48:95-113

Kruczkowska H, Pawlowska H, Skuciñska B (2002) Influence of anther pretreatment on the efficiency of androgenesis in barley. J Appl Genet 43:287-296

Kubaláková M, Doležel J, Lebeda A (1996) Ploidy instability of embryogenic cucumber (Cucumis sativus L.) callus culture. Biol Plant 38:475-480

Kumar S, Bhat V (2012) High-frequency direct plant regeneration via multiple shoot induction in the apomictic forage grass Cenchrus ciliaris L. In Vitro Cell Dev Biol Plant 48:241-248

Labbani Z, Buyser J, Picard E (2007) Effect of mannitol pretreatment to improve green plant regeneration on isolated microspore culture in Triticum turgidum ssp. durum cv. 'Jennah Khetifa'. Plant Breeding 126:565-568

Lambé P, Mutambel HSN, Deltour R, Dinant M (1999) Somatic embryogenesis in pearl millet (Pennisetum glaucum): strategies to reduce genotype limitation and to maintain long-term totipotency. Plant Cell Tissue Organ Cult 55:23-29 
Larkin PJ, Scowcroft SC (1981) Somaclonal variation-a novel source of variability from cell culture for plant improvement. Theor Appl Genet 60:197-214

Leal F, Loureiro J, Rodriguez E, Pais MS, Santos C, Pinto-Carnide O (2006) Nuclear DNA content of Vitis vinifera cultivars and ploidy level analyses of somatic embryo-derived plants obtained from anther culture. Plant Cell Rep 25:978-985

Lim WL, Loh CS (2003) Endopolyploidy in Vanda Miss Joaquim (Orchidaceae). New Phytol 159:279-287

López-Pérez AJ, Carreño J, Martínez-Cutillas A, Dabauza M (2005) High embryogenic ability and plant regeneration of table grapevine cultivars (Vitis vinifera L.) induced by activated charcoal. Vitis 44:79-85

Lysák MA, Doležel J (1998) Estimation of nuclear DNA content in Sesleria (Poacea). Caryologia 52:123-132

Marie D, Brown S (1993) A cytometric exercise in plant DNA histograms, with $2 \mathrm{C}$ values for 70 species. Biol Cell 78:41-51

May RA, Sink KC (1995) Genotype and auxin influence direct somatic embryogenesis from protoplasts derived from embryogenic cell suspensions of Asparagus officinalis L. Plant Sci 108:71-84

Mishiba K, Tawada K, Mii M (2006) Ploidy distribution in the explant tissue and the calluses induced during the initial stage of internode segment culture of Asparagus officinalis L. In Vitro Cell Dev Biol Plant 42:83-88

Murashige T, Skoog F (1962) A revised medium for rapid growth and bioassays with tobacco tissue cultures. Physiol Plant 15:473-497

Murty UR, Bharathi M, Visadara M, Annapurna A (1992) Embryogenic callus formation and plant regeneration in Cenchrus ciliaris (L.). Cereal Res Commun 20:7-12

Niimi Y, Dong-Sheng H, Makoto F (2001) Production of virus-free plantlets by anther culture of Lilium $\times$ 'Enchantment'. Sci Hort 90:325-334

Otto F (1990) DAPI staining of fixed cells for high-resolution flow cytometry of nuclear DNA. In: Crissman HA, Darzynkiewicz Z (eds) Methods in cell biology, vol 33. Academic Press Inc., New York, pp 105-110

Parra-Vega V, Renau-Morata B, Sifres A, Seguí-Simarro JM (2012) Stress treatments and in vitro culture conditions influence microspore embryogenesis and growth of callus from anther walls of sweet pepper (Capsicum annuиm L.). Plant Cell Tissue Organ Cult 112:353-360
Perrin M, Gertz C, Masson JE (2004) High efficiency initiation of regenerable embryogenic callus from anther filaments of 19-grapevine genotypes grown worldwide. Plant Sci 167:1343-1349

Pfosser M, Amon A, Lelley T, Heberle-Bors E (1995) Evaluation of sensitivity of flow cytometry in detecting aneuploidy in wheatrye addition lines. Cytometry 21:387-393

Prado MJ, Rodriguez E, Rey L, González MV, Santos C, Rey M (2010) Detection of somaclonal variants in somatic embryogenesis regenerated plants of Vitis vinifera by flow cytometry and microsatellite markers. Plant Cell Tissue Organ Cult 103:49-59

Rodrigues LR, Oliveira JMS, Mariath JEA, Bodanese-Zanettini ME (2005) Histology of embryogenic responses in soybean anther culture. Plant Cell Tissue Organ Cult 80:129-137

Ross AH, Manners JM, Birch RG (1995) Embryonic callus production, plant regeneration, and transient gene expression following particle bombardment, in the pasture groiss Cenchrus ciliaris (Gramineae). Aust J Bot 43:193-199

Roux N, Toloza A, Radecki Z et al (2003) Rapid detection of aneuploidy using flow cytometry. Plant Cell Rep 21:483-490

Salas P, Prohens J, Seguí-Simarro JM (2011) Evaluation of androgenic competence through anther culture in common eggplant and related species. Euphytica 182:261-274

Snyder LA, Hernandez AR, Warmke HE (1955) The mechanism of apomixis in Pennisetum ciliare. Bot Gaz 116:209-221

Takahata Y, Brown DCW, Keller WA (1991) Effect of donor plant age and infloescense age on microspore culture of Brassica napus L. Euphytica 58:51-55

Tremblay L, Levasseur C, Tremblay FM (1999) Frequency of somaclonal variation in plants of black spruce (Picea mariana, Pinaceae) and white spruce (P. glauca, Pinaceae) derived from somatic embryogenesis and identification of some factors involved in genetic instability. Am J Bot 86:1373-1381

Vikrant A, Rashid A (2002) Somatic embryogenesis from immature and mature embryos of a minor millet Paspalum scrobiculatum L. Plant Cell Tissue Organ Cult 69:71-77

Winarto B, Rachmawati F, Pramanik D, Teixeira da Silva JA (2011) Morphological and cytological diversity of regenerants derived from half-anther cultures of anthurium. Plant Cell Tissue Organ Cult 105:363-374

Yadav CB, Jha P, Mahalakshmi C, Anjaiah V, Bhat V (2009) Somatic embryogenesis and regeneration of Cenchrus ciliaris genotypes from immature inflorescence explants. Biol Plant 53:603-609 